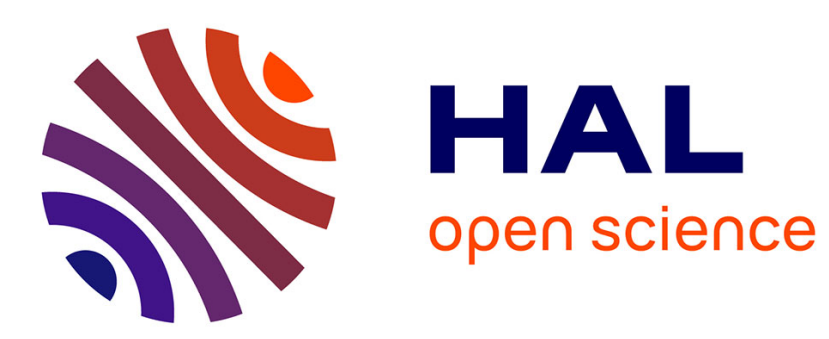

\title{
ARCHAEOLOGY AND TOURISM IN NIGERIA: AN OVERVIEW
}

D S Gubam, T S Nomishan

\section{To cite this version:}

D S Gubam, T S Nomishan. ARCHAEOLOGY AND TOURISM IN NIGERIA: AN OVERVIEW.

Journal of Tourism and Heritage Studies, 2020, 10.33281/JTHS20129.2020.1.7 . hal-03548319

\section{HAL Id: hal-03548319 \\ https://hal.science/hal-03548319}

Submitted on 23 Feb 2022

HAL is a multi-disciplinary open access archive for the deposit and dissemination of scientific research documents, whether they are published or not. The documents may come from teaching and research institutions in France or abroad, or from public or private research centers.
L'archive ouverte pluridisciplinaire HAL, est destinée au dépôt et à la diffusion de documents scientifiques de niveau recherche, publiés ou non, émanant des établissements d'enseignement et de recherche français ou étrangers, des laboratoires publics ou privés. 


\title{
ARCHAEOLOGY AND TOURISM IN NIGERIA: AN OVERVIEW
}

\author{
Gubam, D. S.* \& Nomishan, T.S. \\ Department of Archaeology and Museum Studies, \\ Federal University Lokoja, \\ Kogi State. \\ *Corresponding Author: dimas.gubam@fulokoja.edu.ng \\ DOI: https:/ / doi.org/10.33281/JTHS20129.2020.1.7
}

\begin{abstract}
This paper centres on the role of archaeology in the promotion of the tourism industry in Nigeria. The paper highlights the major roles of archaeology in the progress and development of tourism industry in Nigeria, and note, the unfortunate deliberate non-recognition of the discipline by the tourism sector in the country. It contended that despite this problem, archaeology has done a lot and more is still being done by archaeology and the archaeologists to unveil a lot about the past achievements of Nigerian people. To this end, there is an urgent need for a holistic approach to archaeological research and complete integration of archaeology into the tourism industry in Nigeria. The data for this research was collected through consultation of secondary sources like thesis, textbooks and journals amongst others.
\end{abstract}

Keywords: Archaeology, Archaeologists, Cultural tourism, Museum, Integration

\section{Introduction}

Archaeology is represented in the discipline or practice of tourism by the "Cultural Tourism". The fact that archaeology as a discipline has contributed so much and will continue to do more for the tourism sector of Nigeria remains indisputable. Whether cultural tourism or whichever name it is referred to, the fact remains that archaeology is one of the cardinal pillars holding the tourism sector of Nigeria. Despite this fact, the discipline has not been given the attention it deserves to provide more tourism opportunities for the industry.

The above scenario has resulted in creating several dimensions of unhealthy conditions to some of the archaeological sites that are expected to be protected by the government and the tourism stakeholders. Instead of working hard to reposition more of these sites and give them attractive face that they deserve in the $21^{\text {st }}$ Century, most of the sites are often left at the mercy of their researchers and the host communities who in most cases do not know the importance of the sites and tend to destroy them through activities such as agriculture. Most of the archaeological materials retrieved by archaeologists are often abandoned except for a few that are frequently visited by academic scholars such as the Nok site, Ile Ife and Igbo Ukwu among others. Such archaeological sites, however, have not been listed as tourism sites by the Tourism Board (Okpoko and Okpoko, 2002).

More so, archaeological materials in Nigeria have found their way into different museums where they are displayed to domestic and foreign visitors. 
Archaeologists obtain such materials through techniques that are unique to the discipline, applying some appropriate philosophical orientation (Ogundele, 2006). This is indicative of the fact that archaeology has grown beyond a mere academic exercise in the classroom. The knowledge and training acquired by archaeologists and deployed or applied to solve societal problems have contributed a lot to their ability to identify sites, excavate, analyse and present the materials found in our museums for the consumption of the general public. From the antecedence of archaeological discoveries in Nigeria, it can be seen that archaeological materials are diverse and vibrant. The implication here is that these materials can be well packaged for tourism development which is a clear testimony to support the fact that archaeology should be given its rightful place in the tourism industry in Nigeria.

\section{Conceptual Clarification}

The paper centres on two main concepts that need to be clarified for a proper understanding of the issue the academic piece seeks to address. These concepts include Archaeology and Tourism.

Archaeology: Archaeology is a discipline that studies the history of culture through it material remains (Chard, 1969). This is done through the "recovery, systematic description and study of antiquities" (Clarke, 1968). Though there are other varied definitions of archaeology, its goal remains the reconstruction of past life ways or the generation of models of culture processes (Kirch, 1978). The archaeologist is interested in examining artifacts that have cultural and symbolic values to the human community or human organisation.

Thus, archaeologists obtain their material culture (which is the basic form of information) through excavation which is the main way of recovering data, systematically describing it, classifying or analysing as well as synthesising and generating models or hypothesis on the data retrieved. These models or hypothesis are further tested and modified.

Artifacts are the main materials of the archaeologists. Others are ecofacts and features which are sometimes supplemented by ethnographic data. From these items, the archaeologist extracts his data by subjecting them to thorough laboratory analysis.

Archaeologists believe that all human societies unconsciously left concrete records, not only of their material procession but also of their behaviour, belief system and social institutions. Although these records may be fragmentary and ambiguous, they still can help the archaeologists in the reconstruction of these past human societies.

There are two broad facets of archaeology; prehistoric and historical archaeology. The prehistoric archaeology is concern with people who left no written records. Such societies can be studied through excavation and laboratory analysis of cultural material remains. The historical archaeology, on the contrary, is a concern with societies that left behind kinds of written records and whose activities have been properly documented and which have survived into the present generation. Archaeological studies on historical 
people are usually supplemented by excavation and laboratory analysis of material remains (Hicks and Gloyne, 1996).

In this regard, an archaeologist is, therefore, studying concealed and obscure facets of human behaviour through the peculiar medium of the fossilised and congealed result of this behaviour; hidden in the attributes of ancient artifacts (Clarke, 1968). With advanced approaches to archaeological investigations and studies, more information is being provided towards meeting some of the challenges that are confronting living people (Ogundele, 2006). The implication of this is that archaeological resources in Nigeria are vibrant, diverse as well as challenging and can therefore be packaged for tourism development in the country and beyond.

Tourism: Tourism is a complex phenomenon and has thus been subjected to different definitions. Holloway (1989) defines tourism as "the temporary short-term movement of the people to destinations outside the places where they usually live or work. This could be a movement for all purposes as well as day visit or excursion.

The League of Nations in 1937 recommended that "a tourist" be defined as "one who travels for twenty-four hours or more in a country rather than that in which he usually resides" for pleasure, health, meeting or business. This definition, however, does not handle the case of a tourist who travels within their own countries (Holloway, 1989). The United Nations Conference on International Travel and Tourism in 1963 considered the recommendation of the International Union of Official Travel Organization (now World Tourism Organization) and agreed to describe a tourist as "any person visiting a country (for at least twenty-four hours) other than that in which he has his usual place of residence for any of the following reasons; (a) leisure - whether for recreation, health, sport, holiday, family or meeting; (b) excursion - of less than twenty-four hours including cruise travel - other than following occupation remunerated from within the country visited" (Holloway, 1989).

However, "a visitor who leaves his place of residence for any one or more of the purposes mentioned above but spends a few hours less than earlier stated to achieve his aim can be called a tourist" (Okpoko and Okpoko, 2002). The reason is that once the basic characteristics of tourism emerge, "the use of slightly different categories does not matter" (Hoivik and Heiberg, 1980).

The most common feature of the definition of tourism is that it involves the temporary movement of persons from one destination to another. Such movement must aim at achieving some desired objective and most be within or outside a give geographical boundary. Tourism can be subdivided into domestic and international tourism. The classification is based on the scope or extent of the movement involved. Domestic tourism involves the movement of people within a given geopolitical boundary. This could be for business, leisure, culture, sport and health purposes (Da'silva, 1985). This form of tourism is beneficial to a country in terms of financial benefits. Domestic tourism in Nigeria is restricted within a given state or local government area. 
International tourism involves the movement of people across borders. Each country has rules that control the movement of people coming in and out. In such cases, individuals embarking on this type of tourism are often subjected to serious cheeks at the borders and are expected to meet the requirement of both the immigration and customs of that nation. Both domestic, as well as international tourism are economically beneficial to the host destinations. When properly prosecuted, they can help boost the economic resources of the destinations visited, generate employment opportunities and widen the socio-cultural horizons of both the visited and the visitors (Okpoko and Okpoko, 2002).

Cultural tourist, therefore, moves within or without a country for the purpose of appreciating and/or admiring the artistic potentials of the destination. The individual is therefore visiting archaeological sites or taking a walk in any museum in Nigerian or any other country visited, to see the fascinating archaeological discoveries. In other cases, the individual may also be attending any of the cultural festivals and the likes to witness and /or adequately participate in any of the event showcasing the rich cultural values of Nigeria People.

\section{Archaeological Materials and Nigerian Tourism: An Overview}

Cultural resources are receiving more attention in the developmental effort (including the tourism industry) by different nations in recent times. This has been boosted by the contributions from different international organisations such as UNESCO in the form of aids. Such assistance has been channelled towards the development of that aspect of tourism (Okpoko and Okpoko, 2002). Countries like Iran, Turkey, Indonesia, Pakistan, Brazil, among others, have benefited from such grants aiming at promoting tourism that is culturally based (UNESCO, 1976).

According to UNESCO (1970), Africa's interest in this respect remains minimal as "the countries in the region prefer to give priority to the development of education and science in their use of technical aids". The problem remains that leaders on this part of the world pay more attention to the project that has short-term benefits. In other words, less attention is given to culture and tourism because their perception of this aspect of the economy is that it is not economically beneficial. After all, it cannot attract a lot of funds (Okpoko and Okpoko, 2002). Such negative opinion about cultural tourism emanates from African leaders to think of the long-term benefit (even to the economy) of interest in enduring values (Alagoa, 1988).

In Nigeria, however, the efforts of international organisations, government as well as stakeholders are beginning to yield fruitful results in the integration of cultural resources into the tourism sector. This is helping in the diversification of tourism, thereby making it a multi-disciplinary sector that is accommodating professionals from several fields like archaeology, ethnography, history, geography, sociology, and heritage and museum studies among others. 
More so, Nigeria is blessed with a lot of archaeological potentials as well as archaeological tourism resources (Ogundele, 2006). The sites as well as the artifacts they contain form part of tourism resources. Places that contain material culture, features or ecofacts manufactured or modified by human beings are called sites (Sharer and Ashmore, 1979; Fagan, 2000; Ogundele, 2000; 2002).

Furthermore, Nigerian sites both at the pre-excavation and postexcavation levels have become fascinating tourist centres. Such archaeological sites have been able to give some interesting levels of satisfaction and education to both domestic as well as foreign researchers and tourists (Ogundele, 2006). The artifacts recovered like pottery, sculptures in stone, wood, clay, and metals are usually kept in the museums after proper studies. The degree of impact that these artifacts may have on the tourists, however, depends among other things on the quality of the presentation of such cultural resources in the museum gallery.

According to Agbonten-Eghafona (2002), material culture "displayed within an associative framework tends to reflect their cultural, artistic and technological meaning better than those exhibited in an isolationist and static manner in showcase". In this case, archaeological sites and their finds are beginning to gain attention because of their "tourist attraction" (Hume, 1978; Derefaka, 1988).

Nigeria is integrating archaeological and cultural resources into the tourism sector by harnessing the tourism potentials inherent in our numerous archaeological and historical resources. In the words of Okpoko and Okpoko (2002), "their values could be associative or depending on their ability to evoke in the visitor a remembrance or an understanding of past cultural context in which the cultural resources participated; or informational, which emerges most clearly from formal research in an attempt to understand their relevance to the past human society". On the other hand, their values could be aesthetic in which they can easily appeal to the observers. Archaeological materials can be exploited for tourist purposes.

Viable tourism can be achieved in this case if and when material culture retrieved from archaeological excavations is allowed to play its role properly in the tourism sector, and the ordinary people are enlightened about the importance of such materials. Thus, through archaeological excavations, a lot of artifacts of historical significance have been uncovered in different parts of Nigeria (see figure 1). These materials possess a salient historical and tourism potentials. Their styles also reveal the artistic ability and inventiveness of ancient Nigerian peoples. 


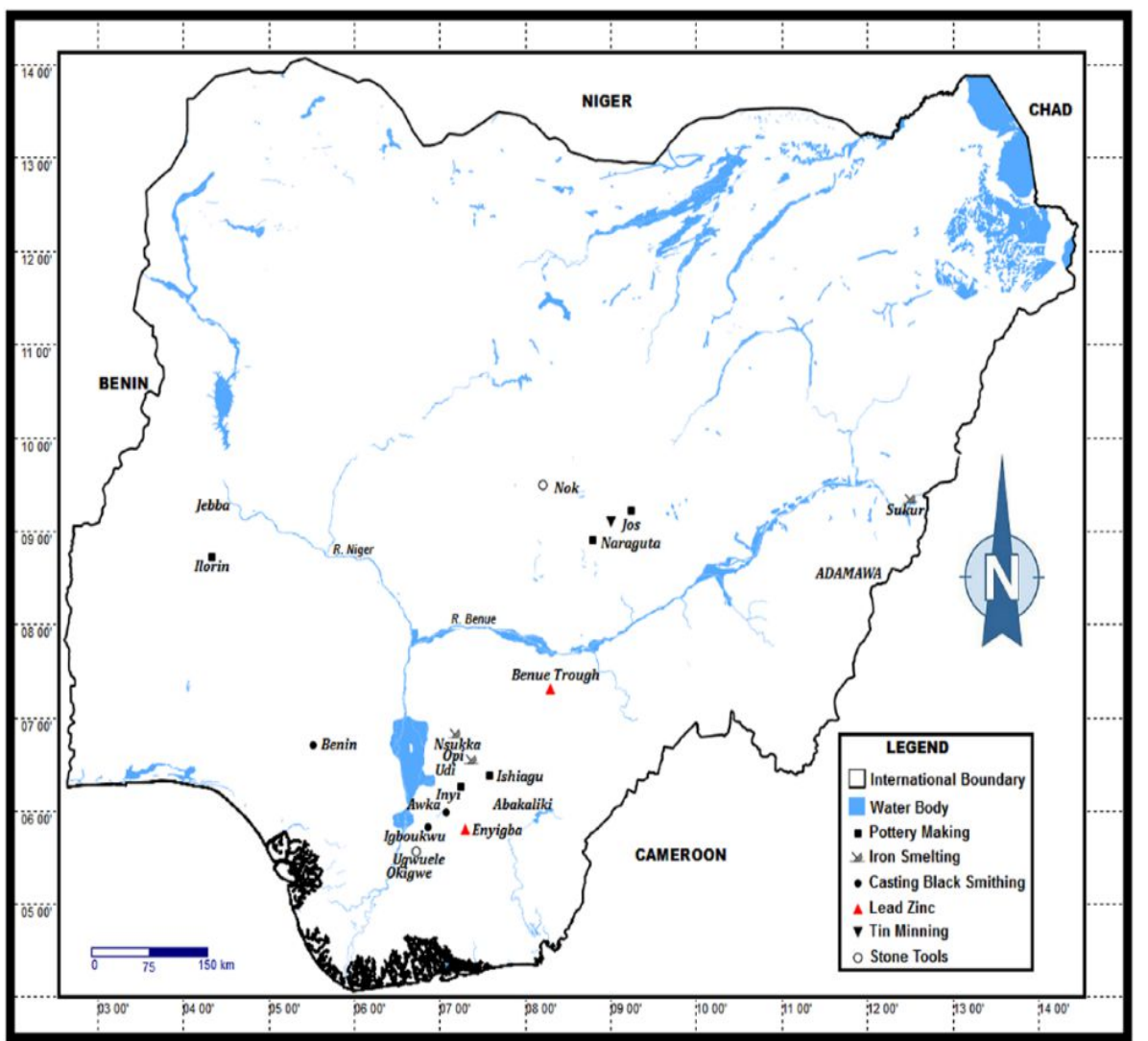

Figure 1: Map of Nigeria Showing the Location of Some Studied Archaeological Sites. Source: Okonkwo and Ibeanu (2016)

Consequently, fascinating discoveries have been made at archaeological sites such as Nok, Ife, Igbo-Ukwu, Benin and Katsina-Ala basin. These locations have provided evidence of centres of ancient civilisations that able to produce materials from iron, copper, bronze, brass and in some cases silver (Andah, 1988). The people were also able to produce beautiful terracotta figurines from clay. All the artistic exploits of these cultures have continued to generate a lot of tourist interest as well as "provided a source of international reputation for Nigeria (see plates 1, 2 and 3). 


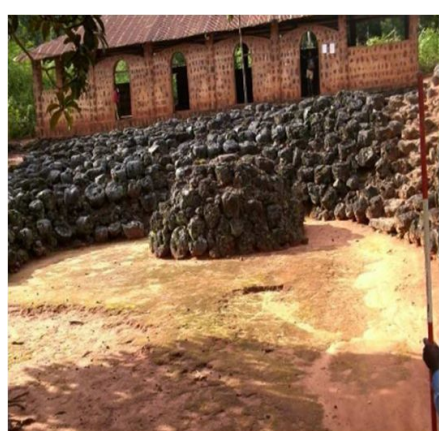

Plate 1: The Cylindrical Iron Blocks at Otobo Ugwu Dunoka, Leja (Agu and Opata, 2012).

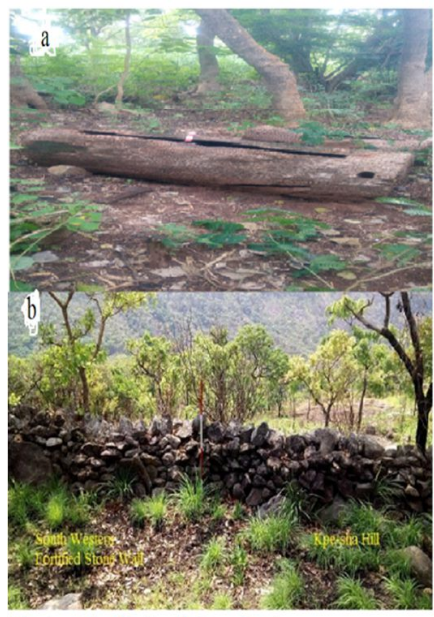

Plate 3: a. Indver ilyu from the Benue Trough

b. Remains of a Fortified Stone Wall in South-eastern Tivland (Nomishan, 2020)
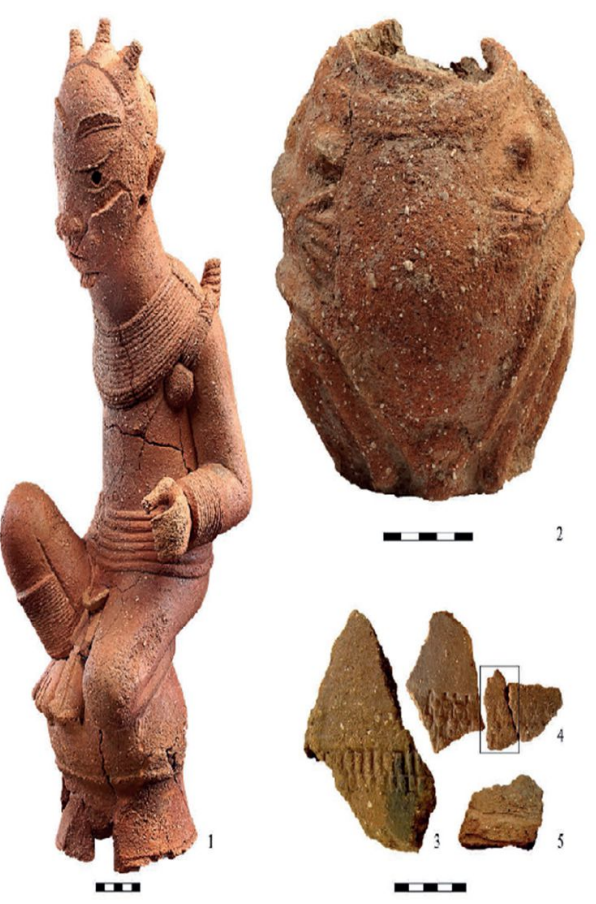

Plate 2: Fired clay objects measured by thermoluminescence in 2013. 1) Terracotta figurine from Daj Gwana; 2) Anthropomorph vessel from Taka Lafiya; 3) Carved roulette potsherd from Ido; 4) Carved roulette potsherd from Tudun Dosa; 5) Potsherd with horizontal application from Pabeki. (Franke, 2016).

The cultural materials retrieved through archaeological processes and kept in Nigerian museums represent the people's indigenous knowledge system. As a result of these discoveries, notable archaeological sites in Nigeria have continued to arouse the interest of different foreign researchers from Europe and America. Nok cultural sites, for instance, have been able to produce the earliest evidence of iron smelting in Africa (Okpoko and Okpoko, 2002). According to Shaw (1975), the remarkable sculpture of Nok culture has been able to evoke the admiration of different people from Europe and America which has made Nok a very popular centre of early civilisation in the world. Most of the finds from Nok can presently be found in different museums in Nigeria.

However, it is not worthy that although the materials from Nok have made the village popular, the Nok village itself is yet to be listed by the Tourist Board of Nigeria as one of the potential tourist sites in the country (Okpoko and Okpoko, 2002). Materials from the sites of Ife, Igbo-Ukwu, Benin as well as the Benue Trough are also deposited and displayed in different museums in Nigeria. National Commission for Museums and Monuments (NCMM) has 
so far declared more than sixty-three historical sites as heritage sites in Nigeria. They include buildings of historical and architectural significance, ancient city walls, cemeteries, Ilojo Bar (in Lagos), Omo-Ukwu temple (in Abia State), Osun Oshgbo shrine (in Osun State), Keffi Madaki house and compound (in Bauchi State) and burial places of important personalities in locations such as Zaria, Kano, Gumel and Lokoja.

Also, ethnographic materials, as mentioned earlier, are valuable cultural resources that have continued to attract the interest of tourists. Some of the ethnographic materials placed in this category are wardresses, traditional and royal crafts, leather works, calabash decorations, woven cloths, ornaments, pottery, and wood carving, among others; thoroughly researched by several professional (see Folorunso 1981, 1993; Ogundele 1990, 1998, Ibeanu, 1992; Simmonds, 1992; Ogundiran, 2002; Aremu and Adekunle, 2005; Ndera 2006; Bakinde and Chia 2011; Haour, 2011; Sule and Haour, 2014; and Nomishan, 2018). These materials are found in and out of the museums in Nigeria (Momin, 1986). Others that equally share in this importance include cultural festivals, traditional dances and drama, among others. For instance, Nkpikiti dance of Umunze, Ijele masquerade of Awka North, Kwagh-hii dance of the Tiv people, Agaba masquerade of the Anambra people, Pus-kat and Nzem Berom of the Jos Plateau, among others. These numerous ethnographic resources in Nigeria can also be harnessed for tourism purposes.

More so, cultural practices in Nigeria have continued to attract a lot of interest among tourists. Traditional festivals are usually celebrated in different places at various seasons of the year, depending on the nature and aim of such festivals. The most popular of these festivals are the new yam festivals like the one celebrated in Igbo land, the Argungu fishing festival (in Kebbi State), fishing festival (in Katsina-Ala), Kyegh Sha Shwa Cultural Festival (in Gboko) and Ogam fishing festival among others. The tourism potentials of these celebrations range from symbolic to informational and aesthetic to economic values (Okpoko and Okpoko, 2002). These festivals draw their spectators from far and near who usually enjoy their spectacular displays, music and delicious meals among others.

In recent times, festivals of arts and culture are organised at national, state or local government levels where cultural dances, as well as materials, are displayed. These festivals are very crucial to the creation of awareness among Nigerian people on the values and importance of our cultural heritage. Alagoa (1988) asserts that "the art and craft of Nigerian people constitute a vast storehouse for modern festival and carnivals". Today, the vast artistic traditions of our past are being modified for economic benefits. The ingenuity of local craft men in using locally sourced materials and the simple tools used in making such materials of high artistic quality is revealed through these cultural traditions (Nwafor, 1982). Some of these articles are purchased by tourists as souvenirs if placed within reach of tourist, whether local or international. 
Nigerian craft men are skilled in blacksmithing, pottery, basketry, leather works, beads making, brass work, and glasswork, among others. Some of these crafts have long histories than claimed by some Eurocentric scholars. However, most of the cultural materials produced in the prehistoric periods have been collected, displayed and preserved in different museums at different locations across the length and breadth of Nigeria.

\section{Conclusion}

Archaeology and tourism discourse in Nigeria are gradually becoming popular in recent times. Archaeology is being integrated into the tourism sector, though not in a large scale. This can, be attributed to the growing awareness of the great potential of the discipline to tourism industry in the country. However, for archaeology to contribute significantly to the progress of tourism sector in Nigeria, the first step is to enhance and promote rigorous archaeological research and results of such research be published and/or packaged for tourism purposes.

Tourism institutions in the country can be remodeled to fully incorporate archaeology. This can be done by creating archaeological departments in such institutions and saddled with the responsibility of researching for sites, preserving them and showcasing them to visitors. For example, the department can employ site guides whose role will be to help visitors in identifying the sites; educating them on the historical background of the sites, meaning of all the cultural materials on the sites and what such sites represent to the history of the community associated with them, amongst others. Craft men can also be engaged to carry out the role of demonstrating the process of making crafts identified on archaeological sites to tourists and this can also help in educating tourists who seek the knowledge for professional purposes.

More archaeological museums can be established in strategic locations in the country with the capacity to house, conserve and preserve the numerous artifacts that are presently being exposed to the danger of been destroyed for lack of conservation and preservation facilities. This can also be an avenue for robust cultural tourism in the country, as it is presently done in countries like Kenya, Egypt, South Africa, Turkey, Britain, U.S.A., and China, amongst others. Thus, owing to the fact that tourism has become a major source of economic growth, employment, and foreign exchange in several nations of the world as also noted by Okoye (2017), absolute integration of archaeology in to the tourism industry of Nigeria can go a long way in shaping the sector for the overall benefit of the nation.

\section{References}

Agbontaen-Eghafona, K. A. (2002). The use of Benin Cultural Objects for Educational Programme in Museums.

Agu, C. S. and \& Opata, C. C. (2012). Iron Technology and Political Power: Examples from the Iron Smelting Belt of Nsukka Area, Enugu State, South- 
Eastern Nigeria. In Research on Humanities and Social Sciences, 2(9), 166175.

Alagoa, E. J. (1988). History. Culture and Tourism. In N. Nzewunwa and A.A. Derefaka; Archaeology, Culture, Tourism and the Nigeria Economy. Proceedings of the $7^{\text {th }}$ Conference of the Archaeological Association of Nigeria. $1^{\text {st }}$ to $8^{\text {th }}$ August, 1988, University of Port Harcourt, Port Harcourt.

Andah, B. W. (1988). African Anthropology. Ibadan, Shaneson C. Ltd.

Aremu, D. A. \& Adekunle, S. K. (2005). Ethnographic Study of the SocioCultural Significance of Calabash Carving in Oyo, Nigeria. West African Journal of Archaeology, 35 (1\&2), 115-133.

Bakinde, C. O. \& Chia, R. T. (2011). Further Archaeological and Ethnographic Survey of Ushongo Area, Benue State, Nigeria. In Journal of Nigerian Field Archaeology, Vol.1, pp. 51-65.

Chard, C. S. (1969). Man in Prehistory. New York, Mc Graw-Hill Book Company.

Clarke, D. L. (1968). Analytical Archaeology. London.

Da'silva, M. C. (1985). Public Service Lecture - Opportunities for Nigeria in the Tourism Industry. Paper presented at the Nigerian Institute of International Affairs. Lagos, 2nd April.

Derefaka, A. A. (1988). Historical Archaeology and Tourism: The Rivers State Example. In (eds) N. Nzewunwa and A.A. Derefaka; Archaeology, Culture, Tourism and the Nigeria Economy. Proceedings of the $7^{\text {th }}$ Conference of the Archaeological Association of Nigeria. $1^{\text {st }}$ to $8^{\text {th }}$ August, 1988, University of Port Harcourt, Port Harcourt.

Fagan, B. (2000). Education is what's Left: some thoughts on the Introductory Archaeology. Antiquity, Vol. 74, No. (283).

Folorunso, C. A. (1981). The Prehistoric Settlements of the Tse Dura and Ushongo Hills: A Preliminary Study. M.Sc Thesis, University of Ibadan.

Folorunso, C. A. (1993). 'Agriculture and Settlement Among the Tiv of Nigeria: Some Ethnoarchaeological Observations'. In The Archaeology of Africa: Food, Metals and Towns. Edited by Thurstan Shaw et al. Pp.274-288. Rutledge. London.

Franke, G. (2016). A Chronology of the Central Nigerian Nok Culture - 1500 $\mathrm{BC}$ to the Beginning of the Common Era. Journal of African Archaeology, Vol. 14 (3), pp., 257--289. DOI 10.3213/2191-5784-10297.

Haour, A. (2011). The archaeology of Hausaland." In Gold, Slaves and Ivory: Medieval Empires in Northern Nigeria. (eds.) D. Gronenborn, 66-69. Mainz: RGZM.

Hicks, D.A. and \& Gloyne, M.A. (1996). Cultural Anthropology. New York. Harper Collin.

Hoivik, T. and \& Heigberg, T. (1980). Cebtre-periphery Tourism and Self Reliance: the Anatomy of Tourism. International Social Science Journal, Vol. xxxii, No. 1. Paris, UNESCO. 
Holloway, J.C. (1989). The Business of Tourism, (3rd Edition). London. Pitman Publishing.

Hume, J.N. (1978). Historical Archaeology. New York. W. Norton and Company Inc.

Ibeanu, A. M. (1992). Pottery Function: An Indispensable Criterion in Igbo Pottery Classification. In B. W. Andah, C. A. Folorunso, I. A. Okpoko (eds.), Imprints of West Africa's Past. (WAJA, Vol. 22, pp. 146-158). Wisdom Publishers Limited Ibadan.

Kirch, P.V. (1978). Ethnoarchaeology and the Study of Agriculture Adaption in Humid Tropics. In Gould, R.A. Explorations in Ethnoarchaeology (eds), . Pp. $103-125$.

Momin, K.N. (1986). Importance of Museums in Nigeria. Mimeograph, Department of Archaeology and Anthropology, University of Ibadan. University of Ibadan Press.

Ndera, J. D. (2006) "Pottery Production in Tivland: An Ethnoarchaeological Perspective" Zaria Archaeological Papers" 10, 78-91.

Nomishan, T. S. (2018). Ethnoarchaeological Study of Pottery Tradition in Usambe, Ikyurav-Ya, South-eastern Tivland, Benue State, Nigeria. Journal of Tourism and Heritage Studies, 7(2), 40-51. DOI: https://doi.org/10.33281/JTHS20129.2017.2.4.

Nomishan, T. S. (2020). An Ethnoarchaeological Investigation of Bako and Kpe Hills, Kwande Local Government Area, Benue State, Nigeria. An Unpublished M.A. Dissertation, A.B.U. Zaria.

Nwafor, J.C. (1982). Historical Development 2: Nigeria Since Independence, Nigeria in Maps. London. Hodder and Stoughton.

Ogundele, S. O. (1990). Archaeological Investigations into Aspects of Tiv Settlement History, Benue Valley Area, Nigeria. Unpublished Ph.D. Thesis, University of Ibadan, Ibadan.

Ogundele, S. O. (1998). 'Aspects of Indigenous TIV Architecture' In K.W. Wesler (Ed) Historical Archaeology in Nigeria (243-258). Trenton and Asmara: Africa World Press.

Ogundele, S. O. (2000). Fundamentals of Archaeology: An Introduction. Ibadan. Ejimasons Nig. Ltd.

Ogundele, S. O. (2002). Archaeological Tourism in Nigeria: Theoretical and Methodological Challenges in the 21 ${ }^{\text {st }}$ Century. Nigeria Heritage, Vol.11.

Ogundele, S. O. (2006). Conceptualising Archaeology and Tourism in Nigeria. In P.U. Okpoko (ed), Issues in Tourism Planning and Development. Nsukka, Afro-Orbis Publishing Ltd.

Ogundiran, A. (2002). Of small things remembered: beads, cowries, and cultural translations of the Atlantic experience in Yorubaland. International Journal of African Historical Studies, 35, 427-457.

Okonkwo, E. E. \& Ibeanu A. M. (2016). Nigeria's Archaeological Heritage: Resource Exploitation and Technology. SAGE Open, April-June, 1-7. DOI: $10.1177 / 2158244016651111$ 
Okoye, C. U. (2017). Tourism Readiness, Investment Promotion, Economic Growth and Development in South East Nigeria: An Expose and Proposal. Journal of Tourism and Heritage Studies, 6 (1), 51-87.

Okpoko, A. I. and \& Okpoko, P.U. (2002). Tourism in Nigeria. Nsukka, AfroOrbis Publishing Ltd.

Sharer, R. J and \& Ashmore, W. (1979). Fundamentals of Archaeology. Menlo Park, California: Benjamin/Cummings Company.

Shaw, T. (1975). The ways Archaeology makes entirely new discoveries about the past. In T. Shaw (ed), Discovering Nigeria's past. Oxford University Press.

Simmonds, D. (1992). A Review of Pottery Technique in Nigeria (1969 - 1970) in a West African Context. In B. W. Andah, C. A. Folorunso, I. A. Okpoko (eds.), Imprints of West Africa's Past. West African Journal of Archaeology, Vol. 22, pp. 146-158. Wisdom Publishers Limited Ibadan.

Sule, S. A. \& Haour, A. (2014): The archaeology of northern Nigeria: trade, people and polities, 1500 BP onwards. Azania: Archaeological Research in Africa. http://dx.doi.org/10.1080/0067270X.2014.968330.

UNESCO, (1970). Protection of Mankind's Cultural Heritage: Sites and Monuments. Paris, UNESCO.

UNESCO, (1976). Field Manual of Museums. Paris UNESCO. 